\title{
Response of Gladiolus Growth and Flowering to Trichoderma and Varieties
}

\author{
Akash Pal, Anjana Sisodia* and Anil K. Singh \\ Department of Horticulture, Institute of Agricultural Sciences \\ Banaras Hindu University, Varanasi, U.P., India \\ *Corresponding author
}

\section{Key words}

Gladiolus,

Cultivars,

Trichoderma,

Growth, Flowering

Article Info

Accepted:

17 June 2018

Available Online:

10 July 2018

\section{A B S T R A C T}

An experiment entitled "Response of gladiolus growth, flowering and corm to Trichoderma and varieties" was carried out at Horticulture Research Farm, Department of Horticulture, Institute of Agricultural Sciences, Banaras Hindu University, Varanasi, (U.P.), during 2017-2018. Experiment consisted of eight varieties of gladiolus namely Yellow Jester, Tiger Flame, Punjab Morning, Punjab Dawn, Pusa Kiran, Shubhangini, IIHR, and Dhanvantri and application of Trichoderma i.e. treated and control. Thus there were sixteen treatment combinations. Experiment was laid out in Randomized Block Design with three replications. Application of Trichoderma was found beneficial for plant growth and flowering characters. Plant treated with Trichoderma show maximum width of leaf and plant height at 60 days. The width of scape also influenced by Trichoderma but there was no any significant effect of Trichoderma on width of scape. Plant treated with Trichoderma show maximum rachis length and longevity of $5^{\text {th }}$ floret. Days to colour show, longevity of $3^{\text {rd }}$ floret and number of open floret without withering first floret are influenced by Trichoderma but there was no any significant influence of Trichoderma. Among different varieties cv. Shubhangini recorded maximum width of leaf at 60 days, whereas in cultivar Yellow Jester exhibited maximum width of scape. The maximum plant height was recorded in cultivar Dhanvantri. The maximum longevity of $3^{\text {rd }}$ and $5^{\text {th }}$ floret was recorded in cultivar Yellow Jester and maximum number of open floret without withering first floret recorded in cultivar Dhanvantri. However maximum rachis length and minimum days to colour show exhibited by cv. IIHR.

\section{Introduction}

Gladiolusis a bulbous ornamental plant that belongs to the family Iridaceae. In commercial floriculture, bulbous ornamental crops are an important group of plants and are considered as the wealth of the country. Gladiolus is an important commercial flower crop and is very popular as cut flower both in domestic and international market. Gladiolus was introduced into cultivation towards the end of sixteenth century. The flowers are used in flower arrangement, in bouquets and for indoor decorations (Singh and Sisodia, 2017). There are over 30,000 varieties of gladiolus. These have mostly been evolved through conventional breeding in USA, The Netherlands, UK, Canada, Russia, Australia, 
Slovakia, Poland, Japan, New Zealand and India whereas a few through mutation breeding in USA, The Netherlands, Russia, Hungary and India (Singh, 2006). All the varieties may not perform well in a region. Therefore, evolution of some promising varieties for a specific region is important. To boost up the yield potential use of bio-agents like Trichoderma plays an important role in enhancing the flowering and growth parameters in gladiolus. Therefore, present investigation has been planned to study the response of gladiolus plant growth and flowering attributes to Trichoderma and varieties.

\section{Materials and Methods}

The experiment was carried out at Horticulture Research Farm of the Department of Horticulture, Institute of Agricultural Sciences, Banaras Hindu University, Varanasi, which is situated at $25^{\circ} 02^{\prime}$ North latitude, $83^{\circ}$ 03' East longitudes and at an elevation of 128.93 meters above the sea level. Eight varieties of gladiolus (Yellow Jester, Tiger Flame, Punjab Morning, Punjab Dawn, PusaKiran, Shubhangini, IIHR, and Dhanvantri) were treated with Trichoderma and also control corms were untreated. Thus, there were sixteen treatment combinations.

Treated and untreated corms were planted with spacing of $30 \mathrm{~cm}$ between the rows and $20 \mathrm{~cm}$ between the plants during December 2017. The experiment was laid out in Randomized Block Design with three replications. Uniform cultural practices were done for all the varieties. Observations were recorded on various growth and flowering parameters and data were analyzed statistically.

\section{Results and Discussion}

\section{Growth characters}

Various growth parameters influenced significantly due to Trichoderma and gladiolus varieties (Table 1). Width of leaf and plant height at 60 days after planting of corms was statistically higher with Trichoderma treatment in comparison to control. However, application of Trichoderma fails to exert any conspicuous effect on width of leaf at 30 days, width of scape at 30 and 60 days and height of crop at 30 days. Although maximum leaf width and plant height was noted in Trichoderma treated plant as reported by Dongardive et al., (2007) and Dubey et al., (2008). Singh and Sisodia (2015) and Singh et al., (2016) also found beneficial effect of Trichoderma in combination with FYM and Vermicompost in gladiolus crop.

All the growth character influenced significantly due to varieties of gladiolus. It is interested to note that maximum width of leaf at 30 days was recorded in cultivar Pusa Kiran followed by IIHR and at 60 days cultivar Shubhangini exhibit maximum leaf width. The maximum width of scape at 30 days was noticed in cultivar Yellow Jester followed by Dhanvantri and at 60 days maximum width of scape was recorded in cultivar Yellow Jester followed by Shubhangini. Maximum plant height at 30 and 60 days recorded with cultivar Dhanvantri which was statistically higher than other varieties. There is wide variation in plant height among the varieties is mainly due to genetic nature of germplasm. Present finding are also in close conformity with the observation made by (Singh et al., 2013a) in tuberose, Singh and Sisodia (2015) and Sisodia et al., (2015) in gladiolus.

\section{Flowering parameters}

Different flowering parameters were influenced significantly due to Trichoderma and gladiolus varieties (Table 2). The plant treated with Trichoderma exhibited maximum longevity of $3^{\text {rd }}$ floret but there was no any significant effect, whereas the maximum longevity of $5^{\text {th }}$ floret was noticed in Trichoderma treated plant. Trichoderma 
treated plant show maximum number of open florets without withering of lower floret, but there was no any significant effect. The rachis length was noticed influenced significantly by Trichoderma. However, application of Trichoderma fail to exert any pronounced effect on days to colour show, longevity of $3^{\text {rd }}$ floret and number of open florets without withering of lower floret. Beneficial effect of application of Trichoderma was also reported by Anuje et al., (2004) and Atta-Alla et al., (2003).

All the flowering parameters except number of open florets without withering of lower floret were influenced significantly due to varieties of gladiolus. Minimum days to colour show was recorded in variety IIHR followed by cv. Punjab Morning, whereas cultivar Tiger Flame was most late to colour show. There is variation in days to colour show among different cultivar as reported by and Singh $e t$ al., (2017). The maximum longevity of $3^{\text {rd }}$ floret was recorded in cultivar Yellow Jester which was statistically at par with cvs. Tiger Flame, Pusa Kiran and Shubhangini are significant to all other varieties. Whereas, cultivar Yellow Jester exhibited maximum longevity of $5^{\text {th }}$ floret followed by Tiger Flame. The maximum number of open floret without withering first floret was recorded in cv. Dhanvantri followed by cv. Tiger Flame. The maximum rachis length was noticed in germplasm IIHR which was statistically at par with Pusa Kiran and significant to all other varieties. Difference on floret length was also found in gladiolus varieties (Fig. 1). Maximum length of $1^{\text {st }}$ floret was exhibited with cv. Dhanvantri, whereas $3^{\text {rd }}$ and $5^{\text {th }}$ floret was maximum in germplasm IIHR. Variation in floret and spike length might be due to variation in their intrinsic factor as reported by various previous workers (Rani and Singh (2005), Pragya et al., (2010), Singh et al., (2017).

Table.1 Response of gladiolus growth to Trichoderma and varieties

\begin{tabular}{|l|r|r|r|r|r|r|}
\hline Treatment & $\begin{array}{l}\text { Width of } \\
\text { leaf at 30 } \\
\text { days (cm) }\end{array}$ & $\begin{array}{l}\text { Width of } \\
\text { leaf at 60 } \\
\text { days }(\mathrm{cm})\end{array}$ & $\begin{array}{l}\text { Width } \\
\text { scape at 30 } \\
\text { days }(\mathrm{cm})\end{array}$ & $\begin{array}{l}\text { Width } \\
\text { scape at 60 } \\
\text { days (cm) }\end{array}$ & $\begin{array}{l}\text { Plant height at } \\
\text { 30 days }(\mathrm{cm})\end{array}$ & $\begin{array}{l}\text { Plant height at } \\
\text { 60 days }(\mathrm{cm})\end{array}$ \\
\hline Bio-agent & & & & & & \\
\hline Control & 1.87 & 2.23 & 1.41 & 1.83 & 30.94 & 45.37 \\
\hline Trichoderma & 1.92 & 2.93 & 1.43 & 1.73 & 29.03 & 52.23 \\
\hline CD at 5\% & $\mathrm{NS}$ & 0.25 & $\mathrm{NS}$ & $\mathrm{NS}$ & $\mathrm{NS}$ & 2.32 \\
\hline Gladiolus varieties & & & & & & \\
\hline Yellow Jester & 1.99 & 3.35 & 1.69 & 2.49 & 23.72 & 40.46 \\
\hline Tiger Flame & 1.35 & 2.57 & 1.27 & 1.69 & 21.08 & 39.57 \\
\hline Punjab Morning & 1.38 & 2.23 & 1.25 & 1.43 & 24.87 & 47.94 \\
\hline Punjab Dawn & 1.50 & 2.34 & 1.20 & 1.55 & 32.64 & 57.04 \\
\hline Pusa Kiran & 2.32 & 2.90 & 1.32 & 1.69 & 33.77 & 48.18 \\
\hline Shubhangini & 1.96 & 3.8 & 1.49 & 2.00 & 25.21 & 40.86 \\
\hline IIHR & 2.23 & 2.54 & 1.47 & 1.68 & 32.36 & 47.15 \\
\hline Dhanvantri & 2.19 & 3.19 & 1.65 & 1.72 & 46.25 & 68.80 \\
\hline CD at 5\% & 0.47 & 0.49 & 0.21 & 0.38 & 4.18 & 4.57 \\
\hline
\end{tabular}


Table.2 Response of gladiolus flowering to Trichoderma and varieties

\begin{tabular}{|l|c|c|c|c|c|}
\hline Treatment & $\begin{array}{c}\text { Days to } \\
\text { colour show }\end{array}$ & $\begin{array}{c}\text { Longevity of } \\
3^{\text {rd }} \text { floret }\end{array}$ & $\begin{array}{c}\text { Longevity } \\
\text { of } 5^{\text {th }} \text { floret }\end{array}$ & $\begin{array}{c}\text { No. of open } \\
\text { floret without } \\
\text { withering of } \\
\text { lower floret }\end{array}$ & $\begin{array}{c}\text { Rachis } \\
\text { length }(\mathrm{cm})\end{array}$ \\
\hline Bio-agent & & & & & \\
\hline Control & 82.30 & 4.75 & 4.51 & 6.30 & 33.68 \\
\hline Trichoderma & 83.70 & 4.83 & 5.23 & 6.59 & 36.81 \\
\hline CD at 5\% & NS & NS & 0.32 & NS & 2.13 \\
\hline Gladiolus varieties & & & & & \\
\hline Yellow Jester & 89.27 & 5.72 & 5.91 & 6.41 & 28.80 \\
\hline Tiger Flame & 90.20 & 5.10 & 5.37 & 6.83 & 34.20 \\
\hline Punjab Morning & 79.77 & 4.48 & 4.73 & 6.29 & 31.75 \\
\hline Punjab Dawn & 81.83 & 4.72 & 4.83 & 6.11 & 32.41 \\
\hline Pusa Kiran & 80.11 & 5.04 & 5.13 & 6.33 & 42.75 \\
\hline Shubhangini & 80.79 & 5.02 & 4.86 & 5.85 & 32.83 \\
\hline IIHR & 78.49 & 4.97 & 4.90 & 5.97 & 43.10 \\
\hline Dhanvantri & 83.61 & 3.30 & 3.57 & 7.78 & 34.14 \\
\hline \multicolumn{1}{|c|}{ CD at 5\% } & 7.81 & 0.77 & 0.63 & NS & 4.24 \\
\hline
\end{tabular}

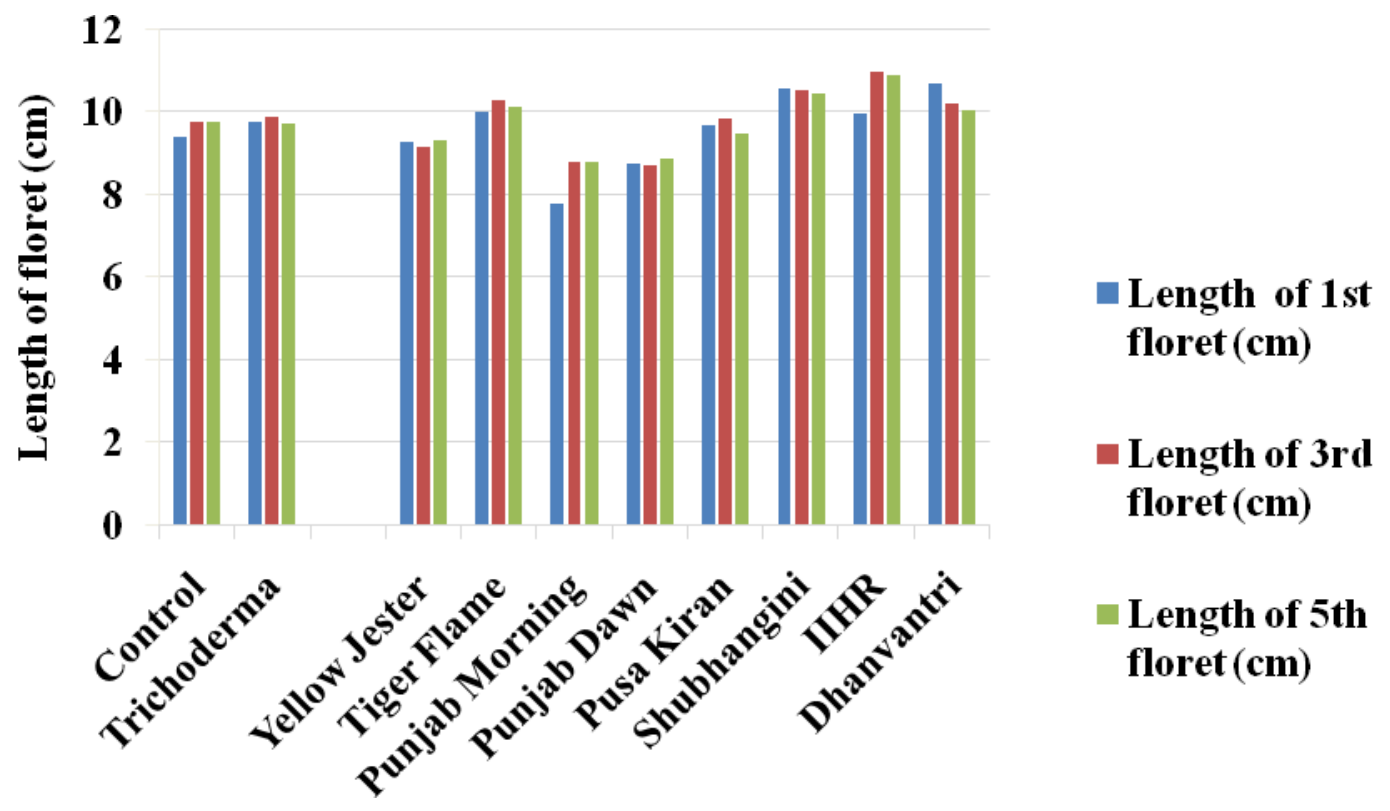

Fig.1 Length of $1^{\text {st }}, 3^{\text {rd }}$ and $5^{\text {th }}$ floret 


\section{References}

Anuje, A.A., Dalal, S.R., Gonge, V.S. and Deshpande, R.M. (2004). Effect of growing media on growth, flowering and yield of gerbera under polyhouse conditions. Orissa Journal of Horticulture, 32 (2): 106-108.

Atta-Alla, H.K., Zaghloul, M.A., Barka, M. and Hashish, K.H. (2003). Effect of organic manure and NPK fertilizers on the vegetative growth, flowering and chemical composition of some gladiolus cultivars. Annals of Agricultural Science, Moshtohor, 41(2): 889-912.

Dongardive, S.B. Golliwar, V.J. and Bhongle, S.A. (2007). Effect of organic manure and biofertilizers on growth and flowering in Gladiolus cv. White Prosperity. Plant Archives, 7 (2): 657658.

Dubey, R.K., Kumar Pankaj and Singh, Narinder (2008). Effect of Trichoderma viride and Pseudomonas fluorescens on growth and flowering of gladiolus. Indian Journal of Ecology, 35(1): 97-98.

Ranjan, J.K., Attri, B.L., Das, B., Hare, K. and N Ahmed (2010). Performance of gladiolus genotypes for cut flower and corm production under high altitude of Uttarakhand. Indian Journal of Horticulture, 67: 386-390.

Rani, R. and Singh, C. (2005). Evaluation of different gladiolus cultivars for quality flower production. Journal of Research Birsa Agricultural
University, 17(2): 227230.

Singh, A. K., Sisodia, A., Sisodia, V. and Ray, P. (2017). Performance of Indian and exotic varieties of gladiolus under Eastern UP conditions. Journal of Ornamental Horticulture, 20(3\&4): 153-157.

Singh, A.K. (2006). Flower Crops: Cultivation and Management, New India Publishing Agency, New Delhi. p. 463.

Singh, A.K. and Sisodia, A. (2017). Textbook of Floriculture and Landscaping. New India Publishing Agency, New Delhi, p. 432.

Singh, A.K., Kumar, A. and Ghimire, N.R. (2013). Performance of Indian and exotic varieties of gladiolus under eastern Uttar Pradesh conditions. Asian Journal of Horticulture, 8(1): 191-194.

Singh, A.K., Kumar, A. and Sisodia, A. (2013a). Growth, flowering and bulb yield in tuberose as influenced by cultivars. Environment and Ecology, 31(4A): 1823-1825.

Singh, A.K., Maurya, K.C., Sisodia, A., Barman, K. and Padhi, M. (2016).Effect of farmyard manure, vermicompost and Trichoderma on plant growth and postharvest life of gladiolus. Journal Ornamental Horticulture, 19(3/4): 75-79.

Sisodia, A. and Singh, A.K. (2015). Effects of farmyard manure, vermicompost and Trichoderma on flowering and corm attributes in gladiolus. Bangladesh Journal of Botany, 44(2): 309-314.

\section{How to cite this article:}

Akash Pal, Anjana Sisodia and Anil K. Singh. 2018. Response of Gladiolus Growth and Flowering to Trichoderma and Varieties. Int.J.Curr.Microbiol.App.Sci. 7(07): 2568-2572. doi: https://doi.org/10.20546/ijcmas.2018.707.301 